\title{
Carcass characteristics and meat quality of sheep fed buffelgrass silage to replace corn silage
}

\author{
E.G. Silva1, G.G.L. Araújo², T.M. Barros e Silva ${ }^{3}$, G.C. Gois ${ }^{3 \#}$, E.M. Santos ${ }^{1}$, J.S. Oliveira1, F.S. \\ Campos $^{4}$, A.F. Perazzo ${ }^{1}$, O.L. Ribeiro ${ }^{5}$ \& S.M. Yamamoto ${ }^{3}$ \\ ${ }^{1}$ Federal University of Paraíba, Animal Production Department, Rod. PB - 079, 58397-000, Areia, Brazil \\ ${ }^{2}$ Brazilian Agricultural Research Corporation, Highway BR-428, Km 152, s/n, Countryside, 56302-970, Petrolina, Brazil \\ ${ }^{3}$ Federal University of Vale do São Francisco, 56304-917, Petrolina, Brazil \\ ${ }^{4}$ Federal Rural University of Pernambuco, Avenue Bom Pastor, s/n, Boa Vista, 55292-270, Garanhuns, Brazil \\ ${ }^{5}$ Federal University of Recôncavo Bahiano, Centre for Agrarian, Environmental and Biological Sciences, 44380-000, \\ Cruz das Almas, Brazil
}

(Submitted 11 September 2019; Accepted 1 January 2021; Published 1 April 2021)
Copyright resides with the authors in terms of the Creative Commons Attribution 4.0 South African License.
See: http://creativecommons.org/licenses/by/4.0/za
Condition of use: The user may copy, distribute, transmit and adapt the work, but must recognize the authors and the South African Journal of Animal Science

\begin{abstract}
The aim of the study was to evaluate the carcass characteristics, proximate composition, and sensorial attributes of meat from sheep fed diets in which buffelgrass silage replaced corn silage. Thirty-two intact male crossbred Santa Inês sheep with an average live weight of $20.09 \pm 2.0 \mathrm{~kg}$ were housed in individual stalls and allotted at random to four treatments in which corn silage was replaced by buffelgrass silage at the levels of 0 (control), $33.3 \%, 66.6 \%$, and $100 \%$. After an adaption period of 10 days, the sheep were fed for an additional 61 days. Feed was offered ad libitum and corn silage comprised $60 \%$ of the diet for the control group. Carcass characteristics, non-carcass components and meat quality were evaluated. Hot carcass yield, cold carcass yield, true carcass yield, trimmings, fat weight, and mesenteric and omental fat weight were highest for the control group $(P<0.05)$. Loin eye area had a quadratic response $(P=0.02)$, with the largest areas being observed in animals fed the diet containing $66.6 \%$ buffelgrass silage. Liver weight $(P$ $<0.01)$, luminosity of the meat $(P<0.05)$, and cooking loss $(P<0.05)$ likewise had nonlinear responses to the concentration of buffelgrass silage in the diet. The treatments did not have significant negative influence on the nutritional and organoleptic characteristics of the meat.
\end{abstract}

Keywords: animal products, diets, sensory analysis, small ruminants

\#Corresponding Author: glayciane_gois@yahoo.com.br

\section{Introduction}

In the semi-arid Caatinga eco-region of north-eastern Brazil, cacti, thick-stemmed plants, thorny brush and arid-adapted grasses provide forage for grazing. Forage production is influenced to a large extent by the rainy and dry seasons. During the rainy season, which lasts for about three months, forage is abundant, and has good nutritional quality. In the dry season, the availability and quality of forage are reduced because of cell wall lignification and decreased crude protein content (Bodner \& Robles, 2017). To manage this situation better, researchers have sought nutritional regimes to increase productivity during periods of drought (Araújo et al., 2017). Among the forages in the Caatinga, buffelgrass (Cenchrus ciliaris L.) stands out because of its adaptation to the adverse climate and its resistance to drought. Buffelgrass produces from 2 to 8 tonnes dry matter (DM)/ha in the region (Bruno et al., 2017) making it an excellent option for silage that is less expensive to produce than corn.

Sheep production is an important enterprise in the Caatinga. The acceptance of sheep meat by consumers results from a combination of its flavour, juiciness, texture, softness, and appearance. The degree to which individual consumers are satisfied with sheep meat depends on their psychological and sensory responses to it. However, its production may be evaluated from the point of view and interest of each producer, downstream industry and the consumer (Sohaib et al., 2017). Thus, the aim of the study was to evaluate the carcass characteristics, proximate composition, and sensory attributes of meat from sheep fed buffelgrass silage (BGS) to replace corn silage (CS). 


\section{Material and methods}

This research was evaluated and approved by the Ethics and Deontology Committee for Studies and Researches of the Federal University of São Francisco Valley under the protocol number 0007/131014. It was conducted in the Animal Metabolism Sector of the Experimental Field of Caatinga, which belongs to the Brazilian Agricultural Research Corporation (Embrapa Semiarid), Petrolina, Brazil. The local average annual precipitation is $570 \mathrm{~mm}$ and average annual maximum and minimum temperatures are $33.5^{\circ} \mathrm{C}$ and $20.9^{\circ} \mathrm{C}$ (Embrapa 2011).

Thirty-two six-month-old intact male crossbred Santa Inês sheep weighing $20.09 \pm 2.0 \mathrm{~kg}$ were used in the experiment. Before the experiment began, the animals were weighed, dewormed, and randomly allotted to individual stalls $(0.80 \times 1.20 \mathrm{~m})$. Each stall was equipped with feed and water toughs. A 10 -day period of adaption preceded the 61-day feeding trial. The sheep were weighed every 15 days.

The experimental design was completely randomized, with four treatments and eight replications. Corn (Zea mays variety Caatingueiro), which was harvested approximately 90 days after planting, and buffelgrass (Cenchrus ciliaris L., variety Biloela), which was harvested about 120 days after germination, were made into silages in $200 \mathrm{~L}$ barrel silos applying $600 \mathrm{~kg} / \mathrm{m}^{3}$ to compact the forage material. In formulating the experimental diets, the silages were augmented with concentrate mixtures that were composed primarily of corn and soybean meal. Samples of the feedstuffs were dried for 72 hours at $55^{\circ} \mathrm{C}$ and ground to $1-\mathrm{mm}$ particles (Wiley Mill, Marconi, MA-580, Piracicaba, Brazil). Dry matter (method 967.03), mineral matter (method 942.05), crude protein (CP) (method 981.10) and ether extract (EE) (method 920.29) were determined (AOAC 2016). Neutral detergent fibre (NDF) and acid detergent fibre (ADF) were assesses (Van Soest et al., 1991). Total carbohydrates (TC) were calculated with the equation proposed by Sniffen et al. (1992). Non-fibrous carbohydrate (NFC) content was calculated as proposed by Hall (2003). Total digestible nutrient content was calculated using the equation of Harlan et al. (1991). Proximate analyses of the silages, corn grain and soybean meal that were used in formulating the diets are shown in Table 1.

Table 1 Proximate analysis of ingredients used to formulate experimental diets for sheep fed diets in which various levels of corn silage were replaced by buffelgrass silage

\begin{tabular}{lrrrrrrrr}
\hline & CS & BGS & $\begin{array}{c}\text { Ground } \\
\text { corn }\end{array}$ & $\begin{array}{c}\text { Soybean } \\
\text { meal }\end{array}$ & C1 & C2 & C3 & C4 \\
\hline $\begin{array}{l}\text { Dry matter (DM), g/kg fresh matter } \\
\text { Constituent, g/kg DM }\end{array}$ & 225.6 & 506.4 & 893.7 & 908.5 & 889.7 & 889.4 & 890.2 & 892.9 \\
$\quad$ & & & & & & & \\
$\quad$ Organic matter & 857.8 & 844.7 & 975.3 & 919.9 & 946.1 & 946.4 & 946.3 & 942.4 \\
$\quad$ Mineral matter & 142.2 & 155.3 & 24.7 & 80.1 & 53.9 & 53.6 & 53.7 & 57.6 \\
$\quad$ Ether extract & 15.3 & 19.0 & 64.2 & 17.9 & 38.6 & 38.4 & 34.0 & 34.0 \\
$\quad$ Crude protein & 60.7 & 53.0 & 99.3 & 498.9 & 290.9 & 310.0 & 320.8 & 352.5 \\
$\quad$ Neutral detergent fibre & 533.6 & 688.1 & 213.9 & 186.1 & 216.3 & 218.9 & 219.0 & 221.8 \\
$\quad$ Acid detergent fibre & 292.3 & 419.9 & 37.9 & 135.8 & 96.1 & 100.2 & 103.2 & 111.3 \\
$\quad$ Non-fibrous carbohydrates & 248.2 & 84.6 & 597.3 & 217.0 & 400.3 & 379.1 & 372.5 & 334.1 \\
$\quad$ Total digestible nutrients & 621.7 & 531.9 & 800.8 & 731.9 & 759.8 & 757.0 & 754.8 & 749.1
\end{tabular}

CS: corn silage; BGS: buffelgrass silage; C1, C2, C3 and C4: concentrate mixtures used in formulating diets varying in CS and BGS contents

Four diets were formulated from these silages and the concentrate mixtures that were characterized in Table 1 (Table 2) Buffelgrass silage replaced CS to produce T1: $100 \%$ CS, T2: $66.6 \%$ CS and $33.3 \%$ BGS, T3: $33.3 \%$ CS and $66.6 \%$ BGS, and T4: 100\% BGS. Each diet was balanced to provide for a projected growth rate of $200 \mathrm{~g} /$ day when fed at a roughage to concentrate ratio of 60 to 40 (dry matter basis) (NRC, 2007). The animals were fed twice a day at $08 \mathrm{~h} 30$ and $15 \mathrm{~h} 30$ and the orts were collected and weighed to determine consumption. The feed offered was adjusted to allow for $10 \%$ orts. 
Table 2 Formulation and proximate analysis of the experimental diets fed to sheep

\begin{tabular}{|c|c|c|c|c|}
\hline Ingredients, g/kg dry matter & T1 & T2 & T3 & T4 \\
\hline Corn silage (CS) & 600.0 & 399.9 & 199.9 & \\
\hline Buffelgrass silage (BGS) & & 199.9 & 399.9 & 600.0 \\
\hline Ground corn & 240.0 & 224.0 & 209.0 & 194.0 \\
\hline Soybean meal & 159.0 & 175.0 & 190.0 & 205.0 \\
\hline Limestone & 0.3 & 0.3 & 0.3 & 0.3 \\
\hline Common salt & 0.5 & 0.5 & 0.5 & 0.5 \\
\hline Premix mineral $^{1}$ & 0.2 & 0.2 & 0.2 & 0.2 \\
\hline \multicolumn{5}{|l|}{ Proximate analysis } \\
\hline Dry matter, $\mathrm{g} / \mathrm{kg}$ fresh matter & 491.2 & 547.2 & 603.7 & 661.0 \\
\hline Organic matter, g/kg dry matter & 893.1 & 890.4 & 887.8 & 883.8 \\
\hline Mineral matter, $\mathrm{g} / \mathrm{kg}$ dry matter & 106.9 & 109.4 & 112.0 & 116.2 \\
\hline Ether extract, g/kg dry matter & 24.6 & 25.3 & 24.3 & 25.0 \\
\hline Crude protein, $\mathrm{g} / \mathrm{kg}$ dry matter & 152.8 & 158.9 & 161.6 & 172.8 \\
\hline Neutral detergent fibre, $\mathrm{g} / \mathrm{kg}$ dry matter & 406.7 & 438.5 & 469.4 & 501.6 \\
\hline Acid detergent fibre, $\mathrm{g} / \mathrm{kg}$ dry matter & 213.8 & 240.9 & 267.6 & 296.5 \\
\hline Non-fibrous carbohydrates, g/kg dry matter & 309.0 & 267.8 & 232.4 & 184.4 \\
\hline Total digestible nutrients, $\mathrm{g} / \mathrm{kg}$ dry matter & 677.0 & 657.7 & 638.9 & 618.8 \\
\hline
\end{tabular}

'Phosphorus: 45 g, calcium: 90 g, chloride: 240 g; sodium: 156 g, sulfur: 10 g, magnesium: 8 g, zinc: 2800 mg, iron: 300 mg, manganese: $2300 \mathrm{mg}$, copper: $150 \mathrm{mg}$, iodine: $40 \mathrm{mg}$, cobalt: $35 \mathrm{mg}$, selenium: $15 \mathrm{mg}$, fluorine: $450 \mathrm{mg}$, BGS: buffelgrass silage, CS: corn silage

T1: $100 \%$ CS, T2: $66.6 \%$ CS and $33.3 \%$ BGS, T3: $33.3 \%$ CS and $66.6 \%$ BGS, T4: $100 \%$ BGS

The sheep were slaughtered at the end of the study period. Before slaughter, the animals were fasted for 16 hours. The animals were then weighed to determine slaughter weight (SW). At slaughter the animals were first stunned, causing cerebral concussion, and then bled by severing the jugular vein and carotid artery in accordance with the Regulation for Inspection of Industrial Sanitation for Products of Animal Origin (Brazil, 2017). After that, the animals were skinned and eviscerated to remove non-carcass components. These components were weighed separately, and percentages were calculated relative to SW.

The carcasses were weighed to determine hot carcass weight (HCW) and hot carcass yield (HCY). The gastrointestinal tract namely stomach and intestines, was separated, and each compartment was weighed full and empty to estimate empty bodyweight (EBW) and true carcass yield (TCY) (Silva Sobrinho et al., 2005).

The carcasses were refrigerated for 24 hours at $4{ }^{\circ} \mathrm{C}$ on hooks to maintain $17 \mathrm{~cm}$ between the tarsometatarsal joints. After chilling, the carcasses were weighed for cold carcass weight (CCW), cold carcass yield $(\mathrm{CCY})$, and chilling loss $(\mathrm{CHL})$. Kidneys and pelvic kidney fat were removed from the chilled carcasses, weighed, and their weight was subtracted from HCW and CCW.

The carcasses were split longitudinally at the midline. The left half-carcass was weighed and cut into six anatomical regions, namely neck, shoulder, rib, loin, leg and breast and flank (Silva Sobrinho et al., 2005). The cuts were weighed (Cezar \& Souza, 2007) immediately to determine their yields relative to halfcarcass weight (Colomer-Rocher, 1987). A cut was made between the 12th and 13th ribs of the right side of the carcass to expose the Longissimus muscle. The loin eye area (LEA) was traced on a transparent plastic film, which was then measured with AutoCAD ${ }^{\circledR}$ software (Autodesk, Inc., San Rafael, California, USA).

The $\mathrm{pH}$ of the meat was measured 24 hours after slaughter with a portable $\mathrm{pH}$ meter (Mettler Toledo International Inc., Columbus, Ohio, United States) (AOAC, 2016). The evaluation of meat colour was conducted on the back section using a transverse cut, and the meat was exposed to the atmosphere for 30 min before the oxygenated myoglobin level was read. Then, after $30 \mathrm{~min}$, the colour values were measured at three points on the inner surface of the muscle, and the average of triplicate measures was calculated separately for each animal, namely $L^{*}$, the index related to luminosity $\left(L^{*}=0\right.$, black; $=100$, white); $a^{*}$, the index that ranges from green $(-)$ to red $(+)$; and $b^{*}$, the index that ranges from blue $(-)$ to yellow $(+)$ (Miltenburg et al., 1992). These measurements were performed with the CIELAB system, which considers 
the $L^{*}, a^{*}$ and $b^{*}$ coordinates responsible for brightness (black/white), red content (green/red) and yellow content (blue/yellow), respectively, with a Minolta CR-10 (Konica® Minolta, Osaka, Japan) colorimeter calibrated from a white ceramic plate with the C illuminant at $10^{\circ}$ for standard observation, being operated with an open cone.

Samples of the Longissimus thoracis muscle were collected from the dorsal-lumbar region at the 10th to 13 th ribs. These samples were then packaged individually and stored at $-20^{\circ} \mathrm{C}$ for subsequent analyses. Before being analysed, the samples were thawed under refrigeration $\left(8^{\circ} \mathrm{C}\right)$ and then dissected with a scalpel to remove the subcutaneous fat. Cooking loss $(\mathrm{CL})$ was determined with samples from the loin that were approximately $1.5 \mathrm{~cm}$ thick, $3.0 \mathrm{~cm}$ long, and $2.5 \mathrm{~cm}$ wide (Duckett et al., 1998). Samples were weighed and cooked in a preheated oven at $170^{\circ} \mathrm{C}$ until the internal meat temperature reached $71^{\circ} \mathrm{C}$, as measured with a copper constant thermocouple equipped with a digital reader. They were then cooled to ambient temperature and reweighed. Cooking loss was determined as the difference in weight of the sample before and after being cooked.

Shear force (SF) was determined according to Wheeler et al. (1995). The samples for this analysis had been cooked after being held at $8^{\circ} \mathrm{C}$ for 24 hours. Two cores were removed from each slice of meat using a $1.27 \mathrm{~cm}$ diameter cork borer that was inserted parallel to the muscle fibres. Each core was sheared perpendicular to the muscle fibres and shear force was measured with a texturometer (GR Manufacturing Co model 3000, Trussville, Al) equipped with a Warner-Bratzler shear blade with a load of $25 \mathrm{kgf}$ (kilogram force) and a cutting speed of $20 \mathrm{~cm} / \mathrm{min}$. Shear force was expressed as $\mathrm{kgf} / \mathrm{cm}^{2}$.

Water-holding capacity (WHC) was measured by placing $0.5 \mathrm{~g}$ samples of the muscle on a $10 \times 10$ $\mathrm{cm}^{2}$ piece of filter paper (Whatman No. 1) between two plexiglass plates, and the sandwich was pressed with a weight of $5 \mathrm{~kg}(71.12 \mathrm{psi})$ for five minutes. The sample was then reweighed and WHC was expressed as a percentage of the initial weight (Wierbicki \& Deatherage, 1958; Honikel \& Hamm, 1994).

The composition of the Longissimus thoracis was determined by thawing the muscle samples for 24 hours at $4 \pm 1{ }^{\circ} \mathrm{C}$. Then the samples were ground for approximately five minutes with a food processor (Mondial, Sao Paulo Brazil) until they became homogenous. Moisture, ash, and protein were measured (AOAC, 2016) with methods 985.41, 920.153 and 928.08. Total lipids were determined in an extractor apparatus (ANKOM Technology, Macedon, New York, USA) (AOCS, 2017).

Sensory evaluation of the meat was performed by a panel of 64 untrained people in a single day. Samples of the $L$. thoracis muscle of each treatment were cut parallel to the muscular fibres into $2.0 \mathrm{~cm}$ cubes (Lyon et al., 1992). These samples were baked in a preheated oven at $170{ }^{\circ} \mathrm{C}$ until the temperature of the geometric centre of the meat cube reached $71^{\circ} \mathrm{C}$, which took on average six minutes. The meat was then wrapped in aluminium foil and maintained in a water bath at $65^{\circ} \mathrm{C} \pm 2{ }^{\circ} \mathrm{C}$. No condiments and salt were added to the meat. The tasting was performed in individual booths under a controlled temperature and adequate lighting conditions. Each evaluator received one cube of each treatment, totalling four samples, which were. were identified by three random digits. The participants were offered water and a cracker to remove residual flavour between samples. The samples were served according to sample position balancing (MacPhie et al., 1999). The colour, aroma, texture, juiciness, and flavour of each attribute were evaluated on an unstructured $9-\mathrm{cm}$ scale (Campos et al., 2017). The anchor points were from extremely light (1) to extremely dark (9) for colour; from extremely weak (1) to extremely strong (9) for aroma; from extremely soft (1) to extremely hard (9) for texture; from extremely dry (1) to extremely succulent (9) for juiciness; from extremely mild (1) to extremely strong (9) for flavour; and from extremely disgusting (1) to extremely liked (9) for the global assessment.

Statistical analyses were performed using the general linear model procedure of SAS (SAS institute Inc., Cary, North Carolina, USA). The data were submitted to one-way analysis of variance and linear and quadratic regression analysis. Probability levels of $P<0.05$ were considered to indicate real differences. The Kruskal-Wallis nonparametric test (Pimentel-Gomes, 1990) was used to analyse the sensory characteristics of meat.

\section{Results and Discussion}

Consumption of EE $(P=0.006)$ and NFC $(P=0.001)$ decreased linearly as more BGS was included in the diet. However, the diets did not affect intake (in g/day) of DM $(P=0.18)$, CP $(P=0.21)$, NDF $(P=0.15)$, $\operatorname{ADF}(P=0.13)$, TC $(P=0.22)$, and TDN $(P=0.27)$ (Table 3$)$. The equation was:

$$
E E=28.67-2.38 x
$$

where $x=$ the level of BGS in the diet, which explained $26 \%$ of the variation in consumption of EE. The mean daily weight gain was $140.16 \mathrm{~g} /$ day (Table 3 ). 
Table 3 Daily consumption of nutritional components and daily weight gain in sheep fed buffelgrass silage to replace corn silage

\begin{tabular}{lccccccc}
\hline Item & $\mathrm{T} 1$ & $\mathrm{~T} 2$ & $\mathrm{~T} 3$ & $\mathrm{~T} 4$ & $\mathrm{SE}$ & $\mathrm{L}$ & $\mathrm{Q}$ \\
\hline Dry matter, g/day & 768.04 & 878.06 & 835.61 & 701.02 & 34.22 & 0.694 & 0.180 \\
Crude protein, g/day & 168.52 & 195.30 & 184.83 & 161.75 & 6.92 & 0.503 & 0.211 \\
Ether extract, g/day & 26.30 & 25.27 & 21.77 & 18.53 & 1.08 & 0.006 & 0.656 \\
Neutral detergent fibre, g/day & 236.99 & 305.93 & 311.44 & 284.06 & 13.86 & 0.145 & 0.058 \\
Acid detergent fibre, g/day & 144.10 & 161.29 & 177.29 & 171.81 & 7.67 & 0.134 & 0.558 \\
Total digestible nutrients, g/day & 649.68 & 724.64 & 740.58 & 538.92 & 32.66 & 0.267 & 0.164 \\
Daily weight gain, g/day & 135.83 & 144.40 & 155.00 & 125.42 & 8.66 & 0.513 & 0.299 \\
Feed conversion & 5.93 & 6.27 & 5.47 & 5.73 & 0.24 & 0.605 & 0.976
\end{tabular}

BGS: buffelgrass silage, CS: corn silage; T1: $100 \%$ CS, T2: $66.6 \%$ CS and 33.3\% BGS, T3: 33.3\% CS and $66.6 \%$ BGS, T4: $100 \%$ BGS included in the diet, L: $P$-value for linear substitution effect, $Q$ : $P$-value for quadratic substitution effect

Hot carcass yield $(P=0.002)$, cold carcass yield (CCY) $(P=0.002)$, and TCY $(P=0.012)$ decreased linearly as the percentage of buffelgrass silage increased in the diets (Table 4). Equations that described these effects were:

$$
H C Y=51.05-1.98 \mathrm{x} \quad C C Y=49.14-2.35 \mathrm{x} \text { and } \quad T C Y=57.76-1.45 \mathrm{x}
$$

where $x=$ the level of BGS in the diet and the equations explained $39 \%, 40 \%$ and $18 \%$ of the variation in the traits. The treatment effects caused no significant differences in SW $(P=0.22)$, EBW $(P=0.15)$, HCW ( $P$ $=0.07)$, CCW $(P=0.08), \mathrm{CHL}(P=0.38)$, and yield of the commercial cuts $(P>0.05)$ (Table 4). The LEA was affected $(P=0.02)$ by the diets, with a maximum value of $11.14 \mathrm{~cm}^{2}$ in animals fed T3 (Table 4). The equation that described the quadratic response in LEA was:

$$
\text { LEA }=8.54+2.51 \mathrm{x}-0.59 \mathrm{x}^{2}
$$

where $x=$ the level of BGS in the diet. This equation explained $29 \%$ of the variation in LEA. The diets had no effect $(P>0.05)$ on carcass conformation score or the degree of finish (Table 4).

Data for the non-carcass components of the lambs are presented in Table 4. Liver weight had a quadratic response $(P<0.01)$ to the increasing level of BGS, being relatively higher in lambs fed T2, and markedly lower in lambs fed T4. Fat trim $(P=0.05)$ and mesenteric and omental fat $(P=0.056)$ decreased linearly as the level of BGS increased. Equations describing these effects on liver weight (LVR), weight fat trim and weight (FT) of the mesenteric and omental fat (IF) were:

$$
\operatorname{LVR}=0.32+0.17 \mathrm{x}-0.04 \mathrm{x}^{2} \quad \mathrm{FT}=0.15-0.05 \mathrm{x} \text { and } \quad \mathrm{IF}=0.85-0.04 \mathrm{x}
$$

where $x=$ the level of BGS in the diet and the equations explained $43 \%, 20 \%$, and $30 \%$ of the variation in the traits. The other non-carcass components were not affected by these treatments $(P>0.05)$.

The treatments influenced $(P<0.05) L^{*}$ of the Longissimus thoracis, $\mathrm{CL}, \mathrm{SF}$, and its moisture content (MC) (Table 5). Equations that described these effects were:

$$
L^{*}=38.22-0.11 x+0.001 x^{2} \quad C L=34.62-0.20 x+0.002 x^{2} \quad S F=1.61+0.008 x \text { and } M C=72.84+0.18 x
$$

where $x=$ the level of BGS in the diet and the equations explained $94 \%, 98 \%, 85 \%$, and $94 \%$ of the variation in the traits. 
Table 4 Carcass characteristics and non-carcass components of sheep fed diets in which buffelgrass silage replaced corn silage

\begin{tabular}{|c|c|c|c|c|c|c|c|}
\hline Carcass characteristic & $\mathrm{T} 1$ & $\mathrm{~T} 2$ & T3 & T4 & SE & L & Q \\
\hline Slaughter weight, $\mathrm{kg}$ & 26.80 & 29.15 & 29.29 & 25.08 & 0.93 & 0.224 & 0.537 \\
\hline Empty bodyweight, kg & 23.29 & 24.96 & 24.66 & 20.67 & 0.84 & 0.151 & 0.539 \\
\hline Hot carcass weight, $\mathrm{kg}$ & 13.11 & 13.52 & 13.59 & 10.98 & 0.46 & 0.073 & 0.555 \\
\hline Cold carcass weight, kg & 12.54 & 12.84 & 12.93 & 10.47 & 0.45 & 0.079 & 0.592 \\
\hline Hot carcass yield, $\%$ & 48.80 & 46.47 & 46.38 & 43.82 & 0.52 & 0.002 & 0.366 \\
\hline Cold carcass yield, \% & 46.66 & 44.16 & 44.10 & 41.76 & 0.50 & 0.002 & 0.333 \\
\hline True yield, \% & 56.27 & 55.08 & 54.32 & 53.24 & 0.51 & 0.012 & 0.332 \\
\hline Chilling loss, \% & 4.41 & 5.07 & 4.79 & 4.67 & 0.15 & 0.380 & 0.854 \\
\hline Carcass conformation score & 3.35 & 3.39 & 3.37 & 3.00 & 0.08 & 0.189 & 0.602 \\
\hline Degree of finish & 3.39 & 3.28 & 3.21 & 3.00 & 0.12 & 0.675 & 0.583 \\
\hline Ribs, \% & 14.94 & 14.80 & 15.01 & 14.55 & 0.36 & 0.898 & 0.369 \\
\hline Neck, \% & 8.93 & 9.04 & 9.25 & 8.57 & 0.30 & 0.716 & 0.356 \\
\hline Shoulder, \% & 18.74 & 18.27 & 18.37 & 19.88 & 0.27 & 0.062 & 0.151 \\
\hline Loin, \% & 8.58 & 9.26 & 9.32 & 8.16 & 0.27 & 0.254 & 0.722 \\
\hline Leg, \% & 29.14 & 30.51 & 29.79 & 30.71 & 0.61 & 0.819 & 0.627 \\
\hline Breast and flank, \% & 10.42 & 9.29 & 9.27 & 9.22 & 0.44 & 0.722 & 0.149 \\
\hline Loin eye area, $\mathrm{cm}^{2}$ & 10.48 & 10.70 & 11.14 & 8.86 & 0.36 & 0.422 & 0.022 \\
\hline Liver, $\mathrm{kg}$ & 0.46 & 0.50 & 0.48 & 0.36 & 0.02 & 0.254 & 0.007 \\
\hline Trimmings fat, $\mathrm{kg}$ & 0.22 & 0.20 & 0.15 & 0.08 & 0.02 & 0.047 & 0.174 \\
\hline Mesenteric + omental fat, $\mathrm{kg}$ & 0.80 & 0.65 & 0.56 & 0.33 & 0.06 & 0.046 & 0.149 \\
\hline
\end{tabular}

BGS: buffelgrass silage, CS: corn silage

T1: $100 \%$ CS, T2: $66.6 \%$ CS and 33.3\% BGS, T3: 33.3\% CS and 66.6\% BGS, T4: $100 \%$ BGS included in the diet, L: $P$ value for linear substitution effect, $Q$ : $P$-value for quadratic substitution effect

Table 5 Mean values of the physical-chemical characteristics of Longissimus thoracis muscle of sheep fed with various levels of replacement of corn silage by buffelgrass silage

\begin{tabular}{|c|c|c|c|c|c|c|c|}
\hline Variable & $\mathrm{T} 1$ & $\mathrm{~T} 2$ & T3 & $\mathrm{T} 4$ & SE & L & $Q$ \\
\hline $\mathrm{pH}$ at 24 hours post mortem & 4.04 & 4.42 & 4.47 & 4.34 & 0.16 & 0.09 & 0.35 \\
\hline Luminosity $\left(L^{*}\right)$ & 38.08 & 36.34 & 35.61 & 38.74 & 0.45 & 0.76 & 0.01 \\
\hline Redness $\left(a^{*}\right)$ & 12.60 & 12.80 & 11.92 & 12.46 & 0.30 & 0.64 & 0.78 \\
\hline Yellowness $\left(b^{\star}\right)$ & 10.36 & 10.03 & 9.60 & 10.17 & 0.19 & 0.55 & 0.23 \\
\hline Cooking loss, \% & 34.82 & 30.12 & 33.0 & 39.64 & 1.17 & 0.11 & 0.02 \\
\hline Shear force, $\mathrm{kgf} / \mathrm{cm}^{2}$ & 1.63 & 1.75 & 2.37 & 2.36 & 0.11 & 0.01 & 0.75 \\
\hline Water-holding capacity, \% & 77.67 & 78.10 & 79.21 & 76.83 & 0.55 & 0.77 & 0.21 \\
\hline Moisture content, \% & 73.02 & 73.21 & 73.91 & 74.76 & 0.16 & 0.01 & 0.31 \\
\hline Ash, \% & 1.1 & 1.1 & 1.2 & 1.1 & 0.09 & 0.89 & 0.93 \\
\hline Protein, \% & 24.83 & 24.18 & 25.39 & 24.23 & 0.26 & 0.81 & 0.63 \\
\hline Lipid content, \% & 2.62 & 2.57 & 2.08 & 2.09 & 0.15 & 0.12 & 0.94 \\
\hline
\end{tabular}

BGS: buffelgrass silage, CS: corn silage; T1: $100 \%$ CS, T2: $66.6 \%$ CS and $33.3 \%$ BGS, T3: $33.3 \%$ CS and $66.6 \%$ BGS, T4: $100 \%$ BGS included in the diet, L: $P$-value for linear substitution effect, $Q$ : $P$-value for quadratic substitution effect 
No difference $(P>0.05)$ was detected for any of the sensory attributes (Table 6$)$.

Table 6 Sensory attributes of Longissimus thoracis muscle of sheep fed various levels of buffelgrass silage to replace corn silage*

\begin{tabular}{lcccccc}
\hline Sensory attribute & T1 & T2 & T3 & T4 & SE & $H$-statistic \\
\hline Colour & 3.74 & 3.65 & 3.37 & 3.14 & 0.222 & 5.69 \\
Aroma & 3.54 & 3.40 & 2.98 & 3.14 & 0.117 & 4.07 \\
Softness & 6.69 & 6.60 & 5.76 & 6.13 & 0.321 & 7.30 \\
Juiciness & 4.41 & 4.39 & 4.59 & 4.80 & 0.199 & 1.33 \\
Flavour & 4.76 & 4.34 & 3.88 & 3.95 & 0.249 & 6.63 \\
Global assessment & 5.69 & 6.05 & 5.87 & 5.90 & 0.414 & 1.99 \\
\hline
\end{tabular}

*Evaluated by 64 judges

BGS: buffelgrass silage, CS: corn silage

T1: 100\% CS, T2: $66.6 \%$ CS and 33.3\% BGS, T3: 33.3\% CS and 66.6\% BGS, T4: 100\% BGS included in the diet,

The sheep grew more slowly than was anticipated, based on the formulations of the nutritionally similar diets that were used in this study. However, similar final and carcass weights were obtained from all of the treatments.

Decreases in carcass yield could be attributed to diet constituents. Oliveira et al. (2018) observed that animals fed diets that were high in fibre and had low digestibility usually promoted lower carcass yield than those that contained less fibre and had higher digestibility. These effects were attributed to differences in gut fill at slaughter, despite the animals have been fasted for the same time. Healthy well-fed animals with high body condition score shave a higher yield because of greater deposition of fat tissue in the carcass (DíazLópez et al., 2017).

The increased amount of BGS in the diet reduced true carcass yield. Leg and loin have the highest commercial values and are thus 'prime' or 'first-class' cuts, given the relatively high proportion of muscle and tenderness (Esteves et al., 2018). However, in this experiment relative amounts of the various cuts were unaffected. Silva Sobrinho et al. (2005) observed that the sum of the leg, loin, and shoulder yields should be above $60 \%$ in meat-producing breeds of sheep. In this study, these yields averaged $57.68 \%$. Breast and flank are known for a small amount of muscle and greater amounts of bone and fat. This greater fat deposition slows the thickening of these cuts. The later growth of these cuts is explained because of their anatomical location whereby a greater fat accumulation is observed in the abdominal region (Andrade et al., 2017). Therefore, the relatively greater amounts of fat trim and mesenteric plus omental fat in CS-fed animals might be because these sheep were fed the diet that was highest in energy (Maciel et al., 2015). Knapik et al. (2017) found that higher energy intake stimulates lipogenesis and hence visceral fat deposition. The similar chilling losses may be because the diets promoted a similar deposition of external fat, preventing weight loss in the carcasses because of evaporation during the refrigeration period.

The observed $\mathrm{pH}$ for sheep meat was around 4.32 (Table 2). This is less than is desired for sheep meat (Gois et al., 2017) since pH values should range from 5.5 to 5.8 at 24 hours after slaughter. This may happen because of the exposure of high-metabolic rate animals to stressful situations, as often occurs before slaughter. Stressed animals often present accelerated metabolism before slaughter and a rapid drop in $\mathrm{pH}$ soon afterwards to the point of compromising meat quality (Kim et al., 2014).

The main meat attributes in the evaluation of meat quality are colour (associated mainly with the decision to buy the meat), softness and aroma and flavour (related to satisfaction of consumption) (Berrighi et al., 2017). Factors that influence colour are related to diet, myoglobin concentration, muscle tissue type, $\mathrm{pH}$, and intramuscular fat concentrations (Jacob \& Pethick, 2014). The diets that were evaluated in this study did not modify the intensity the red colour of the meat. Confinement of the experimental animals possibly favoured lower values of redness since the animals were less active, favouring a lower myoglobin synthesis because of a lower muscle oxygenation, leading to a meat with a less intense colour (Campos et al., 2017). Meat luminosity $\left(\mathrm{L}^{*}\right)$ values ranged from 35.61 to 38.74 , in accordance with the results in other studies, with values higher than 30.0 for sheep meat (Araújo et al., 2017; Berrighi et al., 2017; Campos et al., 2017). These results were possibly influenced by the diets, with less luminous meat being obtained from sheep fed intermediate levels of BGS. However, a rationale for this observation was not apparent. Cooking loss (CL) is a parameter for evaluating meat quality since it is associated with the product yield as it is prepared for 
consumption and influences juiciness and tenderness of the meat (Lima et al., 2018). As with luminosity, cooking loss was lower for meat from sheep fed the intermediate levels of BGS. Shear force of the meat declined linearly as the level of BGS inclusion in the diet increased. The CS-based diet produced meat that would be classified as most tender and the diets that contained more BGS resulted in meat of medium softness (Cezar \& Souza, 2007). The consumer panel did not detect differences in softness that could be attributed to diet.

Higher levels of intra- (marbling) and inter-muscular fat lead to lower CL and hence softer and juicier meat since the meat fat acts as a barrier against moisture loss (Frank et al., 2016). Perceptible sensory differences in sheep meat are caused by variations in fat content (de Lima Junior et al., 2016), as are the characteristic odour and flavour (Kosowska et al., 2017). Generally, as fat deposit increases and the amount of water in the muscle decreases, meat has reduced luminosity and becomes softer (Calnan et al., 2014; Listrat et al., 2016). In the present study, the meat with the highest fat content had a more intense aroma and flavour. The juiciness score increased with the level of BGS in the diet. In the overall assessment, inclusion of BGS in the diet for feeding lambs did not compromise the overall assessment by the panellists.

\section{Conclusions}

Replacing some or all of the CS with BGS in diets for confined Santa Inês sheep did not compromise their carcass characteristics or the nutritional and organoleptic aspects of the meat. Therefore buffelgrass silage could be used as a food source for sheep in semi-arid production systems.

\section{Acknowledgements}

National Council of Scientific and Technological Development (CNPq - Public Call. Ministry of Science, Technology, Innovations and Communications - MCTIC/ CNPq - No. 14/2012 - Universal) is acknowledged for the financial support given to the project 'Silages of varieties of buffelgrass as new alternatives of bulks for diets of sheep in confinement in the Brazilian semiarid'

\section{Authors' Contributions}

EGS, TMBS, GCG, FS, and AFP participated in designing the study, laboratory analysis, and writing the manuscript. GGLA, EMS, JSO, SMY, and OLR drafted and revised the manuscript for intellectual content. EGS, TMBS, GCG, FSC, and SMY carried out data analysis and interpretation and were involved in the preparation and revision of the manuscript. EGS, TMBS, GCG, SMY contributed to the acquisition, analysis and interpretation of data.

\section{Conflict of Interest Declaration}

The authors have no conflicts of interests relative to this project.

\section{References}

Andrade, A.C.S., Macedo, F.A.F., Santos, G.R.A., Queiroz, L.O., Mora, N.H.A.P. \& Macedo, T.G., 2017. Regional composition of carcass and tissue composition of cuts from lambs slaughtered with different subcutaneous fat thicknesses. Semina: Ci. Agr. 38, 2019-2028. http://dx.doi.org/10.5433/1679-0359.2017v38n4p2019

AOAC, 2016. Official methods of analysis. 20th ed. Association of Official Analytical Chemists, Washington DC.

AOCS, 2017. Official methods and recommended practices of the American Oil Official Chemists Society. 7th ed. Washington DC.

Araújo, T.L.A.C., Pereira, E.S., Mizubuti, I.Y., Campos, A.C.N., Pereira, M.W.F., Heinzen, E.L., Magalhães, H.C.R., Bezerra, L.R., Silva, L.P. \& Oliveira, R.L., 2017. Effects of quantitative feed restriction and sex on carcass traits, meat quality and meat lipid profile of Morada Nova lambs. J. Anim. Sci. Biotech. 8, 1-12. http://dx.doi.org/10.1186/s40104-017-0175-3

Berrighi, N., Belkacemi, L., Bouderoua, K., Santaella, M., Ros, G. \& Nieto, G., 2017. Fatty acids composition and sensory properties of lamb meat fed on steppe and highland pastures. Asian J. Anim. Sci. 11, 88-95. http://dx.doi.org/10.3923/ajas.2017.88.95

Bodner, G.S. \& Robles, M.D., 2017. Enduring a decade of drought: Patterns and drivers of vegetation change in a semiarid grassland. J. Arid Env. 136, 1-14. https://doi.org/10.1016/j.jaridenv.2016.09.002

Brazil, 2017. Ministry of Agriculture Livestock And Supply. Regulation of the Industrial and Sanitary Inspection of Products of Animal Origin. Decree No. 9013 of 29 March 2017.

Bruno, L.R.G.P., Antonio, R.P., Assis, J.G.A., Moreira, J.N. \& Lira, I.C.S.A., 2017. Buffelgrass morphoagronomic characterization from Cenchrus germplasm active bank. Rev. Caat. 30, 487-495. http://dx.doi.org/10.1590/198321252017v30n224rc

Calnan, H.B., Jacob, R.H., Pethick, D.W. \& Gardner, G.E., 2014. Factors affecting the colour of lamb meat from the Longissimus muscle during display: The influence of muscle weight and muscle oxidative capacity. Meat Sci. 96, 1049-1057. http://dx.doi.org/10.1016/j.meatsci.2013.08.032

Campos, F.S., Carvalho, G.G.P., Santos, E.M., Araújo, G.G.L., Gois, G.C., Rebouças, R.A., Leão, A.G., Santos, S.A., Oliveira, J.S., Leite, L.C., Araújo, M.L.G.M.L., Cirne, L.G.A., Silva, R.R. \& Carvalho, B.M.A., 2017. Influence of diets with silage from forage plants adapted to the semi-arid conditions on lamb quality and sensory attributes. Meat Sci. 124, 61-68. https://doi.org/10.1016/j.meatsci.2016.10.011 
Cezar, M.F. \& Sousa, W.H., 2007. Sheep and goat carcasses - Obtaining, evaluating and classifying. 1st edition. Uberaba Publishing Company Agropecuária Tropical, Uberaba, MG. 231 pp.

Colomer-Rocher, F.C., Morand-Fehr, P. \& Kirton, A.H., 1987. Standard methods and procedure for goat carcass evaluation, jointing and tissue separation. Liv. Prod. Sci. 17, 149-159. http://dx.doi.org/10.1016/03016226(87)90060-1

De Lima Júnior, D.M., Carvalho, F.F.R., Silva, F.J.S., Rangel, A.H.N., Novaes, L.P. \& Difante, G.S., 2016. Intrinsic factors affecting sheep meat quality: A review. Rev. Colomb. Ci. Pec. 29, 03-15. https://dx.doi.org/10.17533/udea.rccp.v29n1a01

Díaz-López, G., Salazar-Cuytun, R., Herrera, R.G., Piñeiro-Vázquez, A., Casanova-Lugo, F. \& Chay-Canula, A.J., 2017. Relationship between body weight and body condition score with energy content in the carcass of Pelibuey ewes. Austral J. Vet. Sci. 49, 77-81 http://dx.doi.org/10.4067/S0719-81322017000200077

Duckett, S.K., Klein, T.A., Dodson, M.V. \& Snowder, G.D., 1998. Tenderness of normal and callipyge lamb aged fresh or after freezing. Meat Sci. 49, 19-26. https://www.ncbi.nlm.nih.gov/pubmed/22063181

Embrapa, 2011. Brazilian Agricultural Research Corporation. Weather data. http://www.cpatsa.embrapa.br:8080/servicos/dadosmet/ceb-dia.html.

Esteves, G.I.F., Peripolli, V., Menezes, A.M., Louvandini, H., Silva, A.F., Cardoso, C.C. \& McManus, C., 2018. Carcass characteristics and meat quality in cull ewes at different ages. Ci. Anim. Bras. 19, 1-11. http://dx.doi.org/10.1590/1809-6891v19e-33874

Frank, D., Joo, S.T. \& Warner, R., 2016. Consumer acceptability of intramuscular fat. Korean J. Food Sci. Anim. 36, 699708. https://doi.org/10.5851/kosfa.2016.36.6.699

Gois, G.C., Santos, E.M., Sousa, W.H., Ramos, J.P.F., Azevedo, O.S., Oliveira, J.S., Pereira, G.A. \& Perazzo, A.F., 2017. Meat quality of finishing feedlot lambs fed diets of assorted sorghum cultivars. Arq. Bras. Med. Vet. Zootec. 69, 1653-1659. http://dx.doi.org/10.1590/1678-4162-9231

Hall, M.B., 2003. Challenges with nonfiber carbohydrate methods. J. Anim. Sci. 81, 3226-3232. https://doi.org/10.2527/2003.81123226x

Harlan, D.W., Holter, J.B. \& Hayes, H.H., 1991. Detergent fiber traits to predict productive energy of forages fed free choice to nonlactating dairy cattle. J. Dairy Sci. 74, 1337-1353. https://doi.org/10.3168/jds.S0022-0302(91)782891

Honikel, K.O. \& Hamm, R., 1994. Measurement of water holding capacity and juiciness. In: A.M. Pearson \& T.R. Dutson (eds). Quality attributes and their measurement in meat, poultry and fish products. Blackie Academic \& Professional, New York. Pp. 125-161

Jacob, R.H. \& Pethick, D.W., 2014. Animal factors affecting the meat quality of Australian lamb meat. Meat Sci. 96, 1120-1123. http://dx.doi.org/10.1016/j.meatsci.2013.10.039

Kim, Y.H.B., Warner, R.D. \& Rosenvold, K., 2014. Influence of high pre-rigor temperature and fast pH fall on muscle proteins and meat quality: A review. Anim. Prod. Sci. 54, 375-395. http://dx.doi.org/10.1071/AN13329

Knapik, J., Ropka-Molik, K. \& Pieszka M., 2017. Genetic and nutritional factors determining the production and quality of sheep meat - a review. Ann. Anim. Sci. 17, 23-40. http://dx.doi.org/10.1515/aoas-2016-0036

Kosowska, M., Majcher, M.A. \& Fortuna, T., 2017. Volatile compounds in meat and meat products. Food Sci. Tech. 37, 1-7. https://dx.doi.org/10.1590/1678-457x.08416

Lima, A.G.V.O., Oliveira, R.L., Silva, T.M., Barbosa, A.M., Nascimento, T.V.C., Oliveira, V.S., Ribeiro, R.D.X., Pereira, E.S. \& Bezerra, L.R., 2018. Feeding sunflower cake from biodiesel production to Santa Ines lambs: Physicochemical composition, fatty acid profile and sensory attributes of meat. PloS One 13, 1-14. https://doi.org/10.1371/journal.pone.0188648

Listrat, A., Lebret, B., Louveau, I., Astruc, T., Bonnet, M., Lefaucheur, L., Picard, B. \& Bugeon, J., 2016. How muscle structure and composition influence meat and flesh quality. Scient. World J. 2016, 1-14. http://dx.doi.org/10.1155/2016/3182746

Lyon, D.H., Francombe, M.A. \& Hasdell, T.A., 1992. Guidelines for sensory analysis in food product development and quality control. Chapman \& Hall, London.

MacFie, H.J., Bratchell, N., Greenhoff, K. \& Vallis, L.V., 1989. Designs to balance the effect of order of presentation and first-order carry-over effects in hall tests. J. Sens. Stud. 4, 129-148. http://dx.doi.org/10.1111/j.1745459x.1989.tb00463.x

Maciel, M.V., Carvalho, F.F.R., Batista, A.M.V., Guim, A., Souza, E.J.O., Maciel, L.P.A.A., Pereira Neto, J.D. \& de Lima Junior, D.M., 2015. Carcass and non-carcass characteristics of sheep fed on cassava (Manihot pseudoglaziovii Pax \& K. Hoffm.). Chilean J. Agric. Res. 75, 307-312. http://dx.doi.org/10.4067/S0718-58392015000400006

Miltenburg, G.A., Wensing, T., Smulders, F.J. \& Breukink, H.J., 1992. Relationship between blood hemoglobin, plasma and tissue iron, muscle heme pigment, and carcass color of veal. J. Anim. Sci. 70, $2766-2772$. https://www.ncbi.nlm.nih.gov/pubmed/1399893

NRC, 2007. Nutrient requirements of small ruminants: Sheep, goats, cervids, and New World camelids. National Research Council. The National Academy Press, Washington DC. 384 pp.

Oliveira, J.P.F., Ferreira, M.A., Alves, A.M.S.V., Melo, A.C.C., Andrade, I.B., Urbano, S.A., Suassuna, J.M.A., Barros, L.J.A. \& Melo, T.T.B., 2018. Carcass characteristics of lambs fed spineless cactus as a replacement for sugarcane. Asian-Austral. J. Anim. Sci. 31, 529-536. https://doi.org/10.5713/ajas.17.0375

Pimentel-Gomes, F., 1990. Curso de estatística experimental. 12th ed. Nobel, Piracicaba. 467 pp.

Silva Sobrinho, A.G., Purchas, R.W., Kadim, I.T. \& Yamamoto, S.M., 2005. Características de qualidade da carne de ovinos de diferentes genótipos e idades ao abate. Rev. Bras. Zootec. 34, 1070-1078. http://dx.doi.org/10.1590/S1516-35982005000300040 
Sniffen, C.J., O'Connor, J.D. \& Van Soest, P.J., 1992. A net carbohydrate and protein system for evaluating cattle diets: II. Carbohydrate and protein availability. J. Anim. Sci. 70, 3562-3577. https://www.ncbi.nlm.nih.gov/pubmed/1459919.

Sohaib, M. \& Faraz, J., 2017. An insight of meat industry in Pakistan with special reference to halal meat: A comprehensive review. Korean J. Food Sci. Anim. Res. 37, 329-341. http://dx.doi.org/10.5851/kosfa.2017.37.3.329

Van Soest, P.J., Robertson, J.B. \& Lewis, B.A. 1991. Methods for dietary fiber, neutral detergent fiber, and nonstarch polysaccharides in relation to animal nutrition. J. Dairy Sci. 74, 3583-3597. https://doi.org/10.3168/jds.S00220302(91)78551-2

Watkins, P.J., Frank, D., Singh, T.K., Young, O.A. \& Warner, R.D., 2013. Sheepmeat flavor and the effect of different feeding systems: A review. J. Agric. Food Chem. 17, 3561-3579. http://dx.doi.org/10.1021/jf303768e

Wheeler, T.L., Shackelford, S.D. \& Koohmaraie, M. 1995. Shear force procedures for meat tenderness measurement. Clay Center, Marc USDA. https://www.ars.usda.gov/ARSUserFiles/30400510/protocols/shearforceprocedures.pdf.

Wierbicki, E. \& Deatherage, F.E., 1958. Water content of meats, determination of water-holding capacity of fresh meats. Agric. Food Chem. 6, 387-392. https://doi.org/10.1021/jf60087a011 